\title{
The Evaluation of the Possibility to Use the Water from Quarry Lakes for Irrigation
}

\author{
Bartosz Jawecki ${ }^{*}$, Tomasz Kowalczyk², Ye Feng ${ }^{3}$ \\ 1 Wrocław University of Environmental and Life Sciences, Institute of Landscape Architecture, ul. Grunwaldzka 55, \\ 50-357 Wrocław, Poland \\ 2 Wrocław University of Environmental and Life Sciences Institute of Environmental Protection and Development, \\ pl. Grunwaldzki 24, 50-363 Wrocław, Poland \\ ${ }^{3}$ Hunan Agricultural University in Changsha, Horticulture \& Landscape College, No.1 Nongda Road, Furong \\ District, Changsha City, Hunan Province, P.R. China 410128 \\ * Corresponding author's e-mail: bartosz.jawecki@upwr.edu.pl
}

\begin{abstract}
The paper presents the evaluation of the possibility to use the water from five quarry lakes located in County Strzelin for the purposes of agricultural irrigation. The evaluation was based on the guidelines provided by FAO and in PN-84/C-04635. The average values of water quality indicators were as follows: electrical conductivity $0.365 \mathrm{mS} \times \mathrm{cm}^{-1}$; Sodium Adsorption Ratio - 0.75; Total Dissolved Solids - $233.9 \mathrm{mg} \times \mathrm{dm}^{-3}$; water $\mathrm{pH}-7.8 ; \mathrm{BOD}_{5}$ $-1.6 \mathrm{mgO}_{2} \times \mathrm{dm}^{-3}$, while the average ion concentrations were: nitrates $-1.6 \mathrm{mgN}-\mathrm{NO}_{3} \times \mathrm{dm}^{-3}$; sulphates $-188.5 \mathrm{mg}$ $\mathrm{SO}_{4} \times \mathrm{dm}^{-3}$; chlorides $-30.95 \mathrm{mg} \mathrm{Cl} \times \mathrm{dm}^{-3}$; sodium 22.6, mg Na $\times \mathrm{dm}^{-3}$; manganese $-0.05 \mathrm{mg} \mathrm{Mn} \times \mathrm{dm}^{-3}$; and iron $0.04 \mathrm{mg} \mathrm{Fe} \times \mathrm{dm}^{-3}$. The values of the analysed indicators were similar to the concentrations noted in natural lakes and unloaded water reservoirs. The water from the analysed quarry lakes met (with some minor limitations) the requirements that enable its use for agricultural irrigation, in particular sprinkler irrigation.
\end{abstract}

Keywords: quarry lake, water reservoir, quarry, Strzelin quarry lakes, water quality, irrigation, SAR, TDS, EC,

\section{INTRODUCTION}

The deficit of fresh water in the world, including the water for agricultural and industrial needs, was estimated at 230 billion $\mathrm{m}^{3} /$ year in 2000 (Domashenko and Vasilyev, 2018). The water resources are relatively abundant in Europe with a total amount of freshwater of approx. $2270 \mathrm{~km}^{3} /$ year (EEA Report No 2/2009). According to estimations, the European water resources amount, on average, to approx. $4750 \mathrm{~m}^{3} /$ year per person. However, Poland is one of the countries that have poor water resources, with a mean annual discharge of surface waters of approx. $61.2 \mathrm{~km}^{3}$. The average water resource index is $1590 \mathrm{~m}^{3} /$ year per person (Walczykiewicz, 2014; GUS, 2015; Łabędzki; 2016). In many cases, the water is characterised as low quality (Patro and Zubala, 2012). The deficiency and low quality of water, including the water for irrigation, requires solving a number of auxiliary issues, and among other things, the use of irrigation water from different sources, to enhance the efficient utilization of aquatic resources and to reduce the environmental impact (Tarjuelo et al., 2010; Lykhovyd et al., 2019).

Such other water sources may be quarry lakes or pit (mine) lakes that emerge in excavation pits, including quarries, after their operation has been discontinued (Axler et al., 1998; Klapper, Geller, 2001; Ramstedt et al., 2003; Doupé and Lymbery, 2005; Kleeberg and Grüneberg, 2005; Nixdorf et al., 2005; McCullough, 2008; Schultze et al., 2010; Czerniawska-Kusza and Brożonowicz, 2014; Jawecki, 2017; Jawecki et al., 2018; Jawecki and Mirski, 2018). Quarry (pit, mine) lakes may differ in depth, surface area, and capacity, depending on the type of mined resources and mining technology, and they may retain even hundreds of millions 
cubic meters of water (Doyle and Runnells, 1997; Axler et al., 1998; Ramstedt et al., 2003; Denimal et al., 2005; Kleeberg, Grüneberg, 2005; Nixdorf et al., 2005; Molenda, 2006; McCullough and Lund, 2006; Kołodziejczyk, 2009; Schultze et al., 2010; Chudzik, 2012; Singleton et al., 2013; Tokarczyk-Dorociak et al., 2015; Kumar et al., 2016; Jawecki et al., 2018).

The water retained in quarry lakes may be used as a source of potable or industrial water, for the purposes of animal or fish breeding, agricultural or horticultural irrigations etc. (Axler et al., 1998; Klapper and Geller, 2001; Galas, 2003; Castendyk et al., 2005; Doupé and Lymbery, 2005; McCullough and Lund, 2006; McCullough, 2008; Kumar et al., 2009; Schultze et al., 2010; Ravazzani et al., 2011; Singleton et al., 2013). Using the water from flooded pits is particularly important in the areas with scarce water resources (Doupé and Lymbery, 2005; McCullough and Lund, 2006; Kumar et al., 2009; Ravazzani et al., 2011), to which Poland may be included (Patro, Zubala, 2012; Walczykiewicz, 2014). However, the use of water retained in mining pits depends, to a large extent, on its quantity and quality (Doyle and Runnells, 1997; Axler et al., 1998; Grünewald, 2001; Klapper and Geller, 2001; Castendyk et al., 2005; Denimal et al., 2005; Doupé and Lymbery, 2005; McCullough and Lund, 2006; McCullough, 2008; Schultze et al., 2010; Kumar et al., 2016; Jawecki et al., 2018, Jawecki and Mirski, 2018).

The aim of the conducted research was to evaluate the usability of water from quarry lakes located in the flooded quarries of granitoids, quartzite schist and marble in the Strzelin area, for the purposes of agricultural irrigation.

\section{MATERIALS AND METHODOLOGY}

The analyses were conducted in the quarries located in Strzelin County, in the south-eastern part of the Lower Silesian Voivodeship, Poland (Fig. 1). The country is mainly agricultural $\left(523.34 \mathrm{~km}^{2}\right.$ arable land, $59.8 \mathrm{~km}^{2}$ forest areas, wooded, and bushy areas in $622.06 \mathrm{~km}^{2}$ of the county area), with a supplementary function of mining rock material (Jawecki 2017; Jawecki and Mirski, 2018). The Strzelin County is characterised by the presence of metamorphic rocks (gneiss, mica slates, biotite-amphibolite slate, quartzite, quartzite schist, amphibolites, and marble), crossed by numerous veins of acidic magmatic rocks (granitoids - granite, granodiorite, tonalite), as well as basalt, partly covered by sedimentary rocks: silt, clay, and loess. This fostered the exploitation of rock material, and, as a result, led to the presence of over 80 active or closed quarries of various sizes (Jawecki, 2017; Jawecki and Mirski, 2018).

The tests were conducted in 5 flooded quarries ( 3 closed, 2 active, and 1 periodically active), the basic characteristics of which are presented in Table 1. The Q1-G, Q2-TDG, Q3-G, and Q4-QS quarries are non-runoff reservoirs. However, part of the water from the Q1-G and Q4-QS quarries is periodically pumped outside the pit area, while part of the water from the Q5-M quarry is discharged by gravitation to the nearby melioration ditch. The water surface area was determined with use of ArcGIS software based on an orthophotomap (License No. DIO.7211.195.2017_PL_N). The maximum depth of the reservoirs was measured by diving, with use of a gas-switching handheld SUUNTO VYTEC diving computer.

The water for analyses was collected at the depth of $0.5 \mathrm{~m}$ (Brysiewicz et al., 2013), approximately 5-7 $\mathrm{m}$ from the reservoir coast, at 8-10 hours, one a quarter (spring, summer, autumn, winter - with and without ice cover), in the period from December 2016 to March 2018 (Jawecki and Mirski, 2018). The water was analysed at the Faculty Environmental Research Laboratory, pursuant to the reference test methodologies and/or Polish Reference Standards. The authors determined the content of nitrates $\left(\mathrm{NO}_{3}\right)$, sulphates $\left(\mathrm{SO}_{4}\right)$, chlorides, $\mathrm{Na}, \mathrm{Ca}, \mathrm{Mg}, \mathrm{Fe}, \mathrm{Mn}$, as well as the values of $\mathrm{BOD}_{5}, \mathrm{pH}, \mathrm{EC}_{\mathrm{w}}$ (electrical conductivity of water), the SAR index (Sodium Adsorption Ratio - potential sodium hazard from irrigation water), and TDS (Total Dissolved Solids). SAR and TDS were calculated with use of formula 1, 2 (Fig. 2). The mean $\mathrm{pH}$ reaction was calculated from the average value of the concentration of $\left[\mathrm{H}^{+}\right]$ions obtained from the conversion of the initial $\mathrm{pH}$ value. The obtained results were classified according to the FAO guidelines (Ayers and Westcott, 1985) and to the Polish Reference Standard PN-84/C-04635 (Kaniszewski and Treder, 2018). The evaluation was based on the average values from the measurement period, while the value adopted for the overall evaluation was the worst of the analysed indicators. Standard deviation of the average value for $\mathrm{n}<10$, with the $\mathrm{t}$-Student distribution critical value at the degrees of discretion $n-1$, and level of confidence $\mathrm{p}=0.95$ were calculated. 


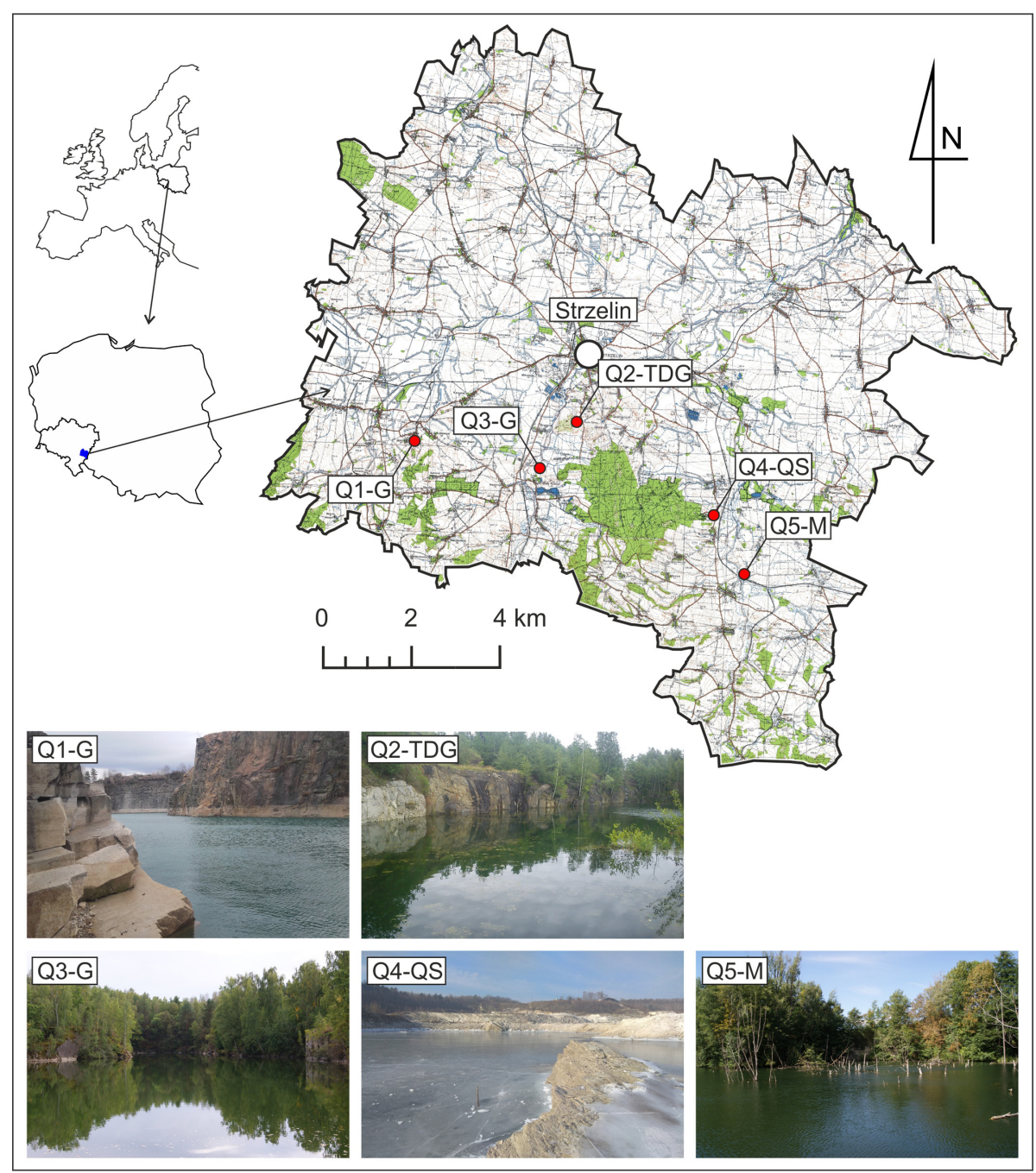

Fig. 1. Location and views of selected Strzelin quarry lakes (topographic background: license No. MGW.I.7522.524.2016_02_N)

\section{RESULTS AND DISCUSSION}

The $\mathrm{pH}$ of the water from flooded quarries fell into the range 7.1-9.0 (Table 2). The average $\mathrm{pH}$ values were in the range of 7.45-8.06 (Fig. 2), where the most often noted $\mathrm{pH}$ value was 8.4. The highest $\mathrm{pH}$ values ( $\mathrm{pH} 9.0$ ) were found in the eutrophic (Jawecki, Mirski, 2018) granite quarry Q3-G. These were noted in spring and summer, which is probably connected with the intensive photosynthesis in the summer season, when the strong development of phytoplanctone and increased photosynthesis may lead to alkalization and increased $\mathrm{pH}$ of water (Puczyńska

Table 1. Basic characteristics of the researched selected Strzelin quarry lakes

\begin{tabular}{|l|c|c|c|c|c|}
\hline \multicolumn{1}{|c|}{ Quarry } & $\begin{array}{c}\text { Code on the } \\
\text { map }\end{array}$ & $\begin{array}{c}\text { Resources } \\
\text { mined }\end{array}$ & $\begin{array}{c}\text { Water } \\
\text { surface area }\end{array}$ & $\begin{array}{c}\text { Maximum } \\
\text { depth }\end{array}$ & Comments \\
\hline Górka Sobocka & Q1-G & Granite & $\sim 3.60$ ha & $\sim 40 \mathrm{~m}$ & Active \\
\hline Biały Kościół/Dębniki & Q2-G & Granite & $\sim 1.25$ ha & $\sim 25 \mathrm{~m}$ & $\begin{array}{c}\text { Closed for } \\
>40 \text { years }\end{array}$ \\
\hline Gęsiniec- Gliczyny & Q3-TDG & $\begin{array}{c}\text { Tonalite, Diorite, } \\
\text { Granite }\end{array}$ & $\sim 2.83$ ha & $\sim 10 \mathrm{~m}$ & $\begin{array}{c}\text { Closed for } \\
<10 \text { years }\end{array}$ \\
\hline Jegłowa & Q4-QS & Quartzite schist & $\sim 1.10$ ha & $\sim 16 \mathrm{~m}$ & $\begin{array}{c}\text { Periodically } \\
\text { active } \\
\text { Active }\end{array}$ \\
\hline Przeworno & Q5-M & Marble & $\sim 0.89$ ha & $\sim 10 \mathrm{~m}$ & $\begin{array}{c}\text { Closed for } \\
>40 \text { years }\end{array}$ \\
\hline
\end{tabular}


Table 2. Average, minimum and maximum value of analysed indicators of water in selected Strzelin quarry lakes

\begin{tabular}{|c|c|c|c|c|c|c|}
\hline Item & Parameter & Q1-G & Q2-TDG & Q3-G & Q4-QS & Q5-M \\
\hline 1. & $\begin{array}{l}\mathrm{pH} \\
(-)\end{array}$ & $\frac{8.06}{7.6-8.4}$ & $\frac{7.98}{7.6-8.4}$ & $\frac{7.73}{7.2-9.0}$ & $\frac{7.45}{7.1-8.2}$ & $\frac{7.90}{7.5-8.4}$ \\
\hline 2. & $\begin{array}{l}E C_{w} \\
\left(\mathrm{mS} \times \mathrm{cm}^{-1}\right)\end{array}$ & $\frac{0.353 \pm 0.029}{0.321-0.384}$ & $\frac{0.288 \pm 0.020}{0.270-0.311}$ & $\frac{0.384 \pm 0.021}{0.369-0.407}$ & $\underline{0.183 \pm 0.014}$ & $\frac{0.619 \pm 0.050}{0.589-0.681}$ \\
\hline 3. & $\begin{array}{l}\text { SAR } \\
(-)\end{array}$ & $\frac{0.35 \pm 0.08}{0.25-0.42}$ & $\frac{0.38 \pm 0.09}{0.30-0.49}$ & $\frac{0.69 \pm 0.09}{0.58-0.77}$ & $\frac{0.36 \pm 0.04}{0.32-0.39}$ & $\frac{1.96 \pm 0.48}{1.62-2.59}$ \\
\hline 4. & $\begin{array}{l}\text { TDS } \\
\left(\mathrm{mg} \times \mathrm{dm}^{-3}\right)\end{array}$ & $\frac{226.0 \pm 18.3}{205.4-245.8}$ & $\frac{184.2 \pm 12.9}{172.8-199.0}$ & $\frac{245.9 \pm 13.4}{236.2-260.5}$ & $\frac{117.1 \pm 9.0}{104.3-121.6}$ & $\frac{396.0 \pm 31.7}{377.0-435.8}$ \\
\hline 5. & $\begin{array}{l}\mathrm{BOD}_{5} \\
\left(\mathrm{mg} \mathrm{O}_{2} \times \mathrm{dm}^{-3}\right)\end{array}$ & $\frac{1.32 \pm 1.37}{0.60-3.20}$ & $\frac{1.54 \pm 1.04}{0.90-2.90}$ & $\frac{2.04 \pm 1.53}{1.00-4.10}$ & $\frac{1.46 \pm 1.32}{0.30-2.80}$ & $\frac{1.42 \pm 0.60}{0.80-1.90}$ \\
\hline \multirow{2}{*}{6.} & $\begin{array}{l}\text { Nitrates } \\
\left(\mathrm{mg} \mathrm{NO}_{3} \times \mathrm{dm}^{-3}\right)\end{array}$ & $\frac{33.48 \pm 1.34}{31.72-34.51}$ & $\frac{0.84 \pm 0.45}{0.49-1.33}$ & $\frac{0.43 \pm 0.45}{0.00-0.97}$ & $\frac{0.58 \pm 0.47}{0.66-0.61}$ & $\frac{0.30 \pm 0.25}{0.00-0.44}$ \\
\hline & $\left(\mathrm{mg} \mathrm{N}-\mathrm{NO}_{3} \times \mathrm{dm}^{-3}\right)$ & $\frac{7.56 \pm 0.30}{7.16-7.79}$ & $\frac{0.19 \pm 0.10}{0.11-0.3}$ & $\frac{0.098 \pm 0.10}{0.00-0.22}$ & $\underline{0.13 \pm 0.11}$ & $\frac{0.068 \pm 0.06}{\underline{0.00-0.1}}$ \\
\hline 7. & $\begin{array}{l}\text { Sulphates } \\
\left(\mathrm{mg} \mathrm{SO}_{4} \times \mathrm{dm}^{-3}\right)\end{array}$ & $\frac{218.54 \pm 283.13}{13.20-606.40}$ & $\frac{233.48 \pm 192.31}{83.10-496.10}$ & $\frac{168.82 \pm 182.43}{8.20-408.10}$ & $\frac{156.32 \pm 247.24}{7.40-503.50}$ & $\frac{165.22 \pm 199.56}{17.30-438.60}$ \\
\hline 8. & $\begin{array}{l}\text { Chlorides } \\
\left(\mathrm{mg} \mathrm{Cl} \times \mathrm{dm}^{-3}\right)\end{array}$ & $\frac{21.16 \pm 6.37}{16.60-30.00}$ & $\frac{15.20 \pm 1.45}{13.40-16.60}$ & $\frac{56.92 \pm 6.55}{47.60-60.40}$ & $\frac{22.04 \pm 3.74}{17.00-25.00}$ & $\frac{39.44 \pm 5.11}{32.60-43.80}$ \\
\hline 9. & 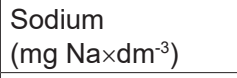 & $\frac{10.98 \pm 2.64}{7.70-13.50}$ & $\frac{9.78 \pm 2.34}{7.50-12.60}$ & $\frac{19.74 \pm 2.69}{16.50-22.30}$ & $\frac{6.98 \pm 0.93}{5.80-7.60}$ & $\frac{65.72 \pm 14.67}{55.90-85.00}$ \\
\hline 10. & $\begin{array}{l}\text { Calcium } \\
\left(\mathrm{mg} \mathrm{Ca} \times \mathrm{dm}^{-3}\right)\end{array}$ & $\frac{60.90 \pm 5.04}{56.70-66.70}$ & $\frac{42.08 \pm 5.03}{38.40-49.00}$ & $\frac{48.32 \pm 2.45}{46.60-51.70}$ & $\frac{21.44 \pm 1.58}{19.60-22.40}$ & $\frac{58.54 \pm 4.31}{54.00-62.10}$ \\
\hline 11. & 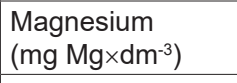 & $\frac{7.20 \pm 0.38}{6.80-7.50}$ & $\frac{5.34 \pm 0.46}{5.10-6.00}$ & $\frac{8.82 \pm 0.79}{8.10-9.80}$ & $\frac{4.00 \pm 0.32}{3.60-4.20}$ & $\frac{16.48 \pm 0.92}{15.40-17.40}$ \\
\hline 12. & $\begin{array}{l}\text { Manganese } \\
\left(\mathrm{mg} \mathrm{Mn} \times \mathrm{dm}^{-3}\right)\end{array}$ & $\frac{0.008 \pm 0.016}{0.000-0.030}$ & $\frac{0.024 \pm 0.023}{0.000-0.040}$ & $\frac{0.089 \pm 0.196}{0.000-0.370}$ & $\frac{0.030 \pm 0.035}{0.000-0.060}$ & $\frac{0.090 \pm 0.155}{0.000-0.310}$ \\
\hline 13. & $\begin{array}{l}\text { Iron } \\
\left(\mathrm{mg} \mathrm{Fe} \times \mathrm{dm}^{-3}\right)\end{array}$ & $\frac{0.016 \pm 0.023}{0.000-0.040}$ & $\frac{0.060 \pm 0.106}{0.000-0.210}$ & $\frac{0.002 \pm 0.006}{0.000-0.010}$ & $\frac{0.078 \pm 0.114}{0.001-0.220}$ & $\frac{0.040 \pm 0.061}{0.000-0.120}$ \\
\hline
\end{tabular}

and Skrzypski, 2009; Wiejaczka, 2011). Similar results ( $\mathrm{pH}$ 7.7-8.4) were obtained by Galas (2003), Czerniawska-Kusza and Brożonowicz (2014), Jawecki, Mirski (2018) in flooded quarries of marble, lime, and quartzite, while higher values ( $\mathrm{pH}$ 7.34-9.74) were noted by Mayne (1994) who analysed the limestone quarries in Nebraska (USA), and Jawecki and Mirski (2018) obtained the $\mathrm{pH}$ values of 7.2-9.3 in eutrophic granite quarries. Only in the Q3-G quarry did the $\mathrm{pH}$ value of 9.0, 8.6 exceed the range that is characteristic for natural lakes ( $\mathrm{pH} 6.5-8.5)$ and the range (pH 6.5-8.4) recommended by FAO for water used in irrigation (Ayers and Westcott, 1985). In $56 \%$ of the analysed water samples, the $\mathrm{pH}$ exceeded 8.0 (usually in summer), which is recommended for irrigation in Poland (PN-84/C-04635; Kaniszewski and Treder, 2018).

In most of the analysed quarry lakes (Q1-G, Q2-TDG, Q3-G, Q4-QS), the water was characterised by low $\mathrm{EC}_{\mathrm{w}}$, below $0.5 \mathrm{mS} \times \mathrm{m}^{-1}$ (Tab. 2), which is characteristic for $80 \%$ of Polish lakes (Hobot, 2014). The average value of $\mathrm{EC}_{\mathrm{w}}$ fell into the range of $0.183-0.384 \mathrm{mS} \times \mathrm{cm}^{-1}$ (Fig. 2). On the other hand, in quarry Q5-M (Tab. 2, Fig. 2) the average value of $\mathrm{EC}_{\mathrm{w}}$ was $0.619 \mathrm{mS} \times \mathrm{cm}^{-1}$ $\left(0.589-0.681 \mathrm{mS} \times \mathrm{cm}^{-1}\right)$, but it did not exceed 1
$\mathrm{mS} \times \mathrm{cm}^{-1}$ (very high) (Hobot 2014). It should be noted that quarry lakes are quite often salinized, and characterised by $\mathrm{EC}_{\mathrm{w}} 1 \mathrm{mS} \times \mathrm{cm}^{-1}$, reaching up to $3 \mathrm{mS} \times \mathrm{cm}^{-1}$, or even over $20 \mathrm{mS} \times \mathrm{cm}^{-1}$ (Ramstedt et al., 2003, Galas 2003, Denimal et al., 2005, Schultze et al., 2010, Kumar et al., 2016). Marls and limestone quarry lakes fall into the range of $0.481-0.653 \mathrm{mS} \times \mathrm{cm}^{-1}$ (Czerniawska-Kusza and Brożonowicz, 2014), silica sand quarry lake $1.2 \mathrm{mS} \times \mathrm{cm}^{-1}$ (Kumar et al., 2009), quartzites and quarzitic sandstones quarry lakes

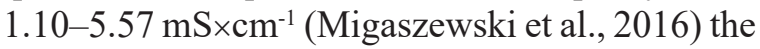
quarry lakes of the Strzelin area that emerged in granitoid, quartzite and marble quarries are characterised by $\mathrm{EC}_{\mathrm{w}}$ below $0.7 \mathrm{mS} \times \mathrm{cm}^{-1}$ (Jawecki and Mirski, 2018). In the guidelines provided in the paper by Kaniszewski and Treder (2018), the water in the Q4-QS quarry lake has a low degree $\left(0-0.25 \mathrm{mS} \times \mathrm{cm}^{-1}\right)$ of salination, while in the other flooded quarries, the salination is medium

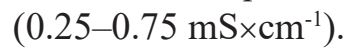

The value of the TDS indicator fell into the range of $104.3-435.8 \mathrm{mg} \times \mathrm{dm}^{-3}$, with average values in the range of $117.1-396.0 \mathrm{mg} \times \mathrm{dm}^{-3}$. The highest values were noted in the Q5-M quarry lake (aver-

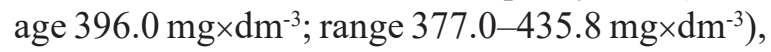
and the lowest in the quartzite schist 

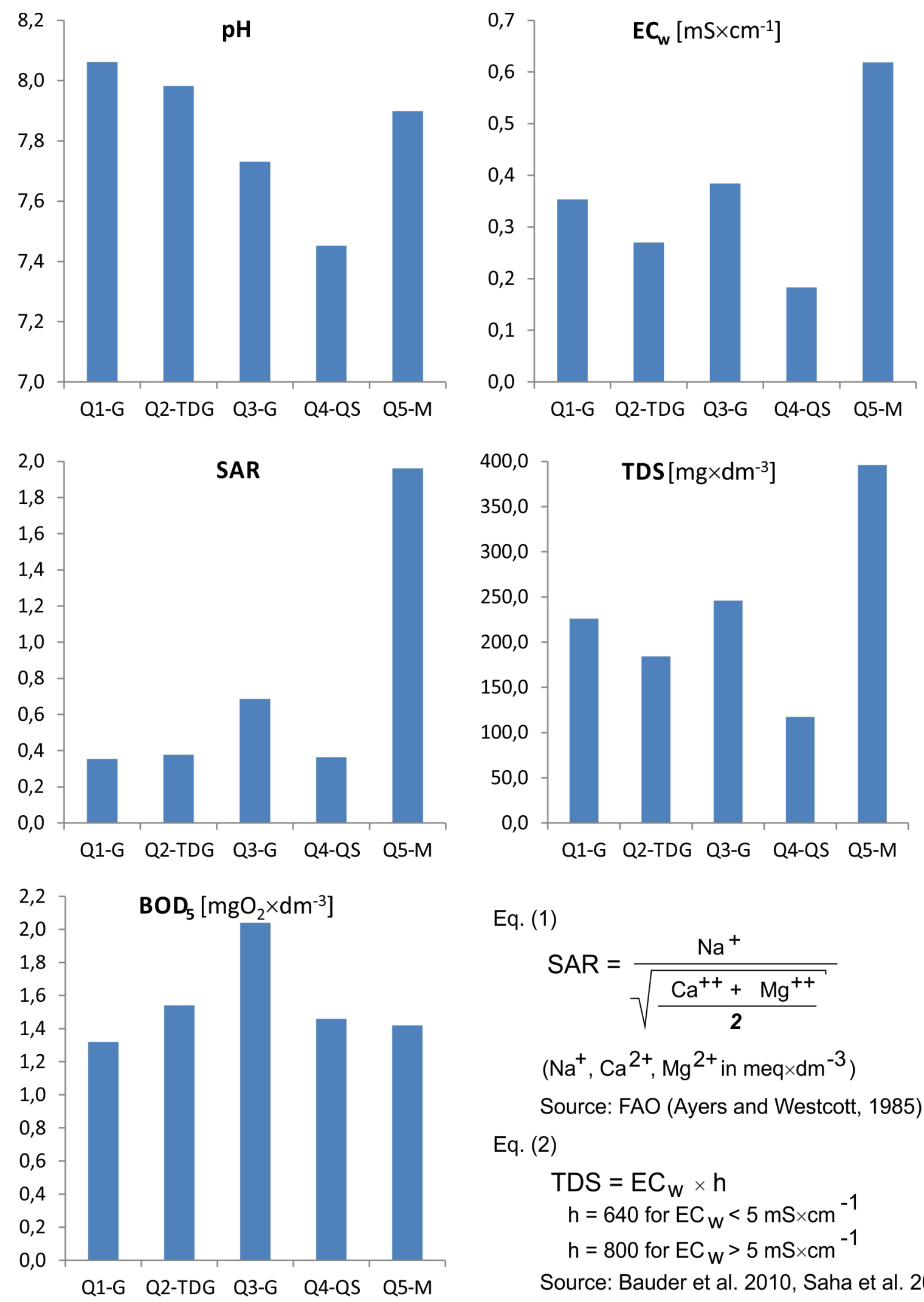

Eq. (1)

$$
\begin{gathered}
\mathrm{SAR}=\frac{\mathrm{Na}^{+}}{\sqrt{\frac{\mathrm{Ca}^{++}+\mathrm{Mg}^{++}}{2}}} \\
\left(\mathrm{Na}^{+}, \mathrm{Ca}^{2+}, \mathrm{Mg}^{2+} \text { in meq } \times \mathrm{dm}^{-3}\right)
\end{gathered}
$$

Source: FAO (Ayers and Westcott, 1985)

Eq. (2)

$$
\begin{aligned}
& \text { TDS }=E C_{W} \times h \\
& h=640 \text { for } E C_{W}<5{\mathrm{mS} \times \mathrm{cm}^{-1}}^{-1} \\
& \mathrm{~h}=800 \text { for } E C_{\mathrm{W}}>5 \mathrm{mS} \times \mathrm{cm}^{-1}
\end{aligned}
$$

Source: Bauder et al. 2010, Saha et al. 2015

Fig. 2. Average values of the indicators that characterise the usability of water from selected quarry lakes in the Strzelin area for irrigation and SAR, TDS index equations 
quarry Q4-QS (average $117.1 \mathrm{mg} \times \mathrm{dm}^{-3}$; range $\left.104.3-121.6 \mathrm{mg} \times \mathrm{dm}^{-3}\right)$, which is drained quite regularly (Table 2, Fig. 2). The SAR index of the waters in the analysed quarries fell into the range of 0.25-2.59 (Table 2), with the average values ranging from $0.35-1.96$ (Fig. 2). The highest values were noted in the eutrophic (Jawecki and Mirski, 2018), flooded marble quarry Q5-M (average 1.96; range 1.62-2.59), and the lowest in the active quarries: Q1-G granite quarry (average 0.35; range $0.25-0.42$ ) and quartzite schist quarry Q4-QS (average 0.36; range 0.32-0.39) (Table 2, Fig. 2).

The $\mathrm{EC}_{\mathrm{w}}$ value of water in all analysed quarry lakes does not exceed $0.7 \mathrm{mS} \times \mathrm{cm}^{-1}$ and TDS does not exceed $450 \mathrm{mg} \times \mathrm{dm}^{-3}$ which means that it may be freely used for irrigation (Bauder et al. 2010, Sayer et al. 2015; Kaniszewski and Treder, 2018). However, the assessment of sodium hazard of irrigation water based on SAR and $\mathrm{EC}_{\mathrm{w}}$, evaluated using $\mathrm{EC}_{\mathrm{w}}$ and SAR together (Ayres and Wescot, 1985; Bauder et al., 2010, Sayer et al., 2015) demonstrates that in spite of low SAR index $(<3)$ of the analysed quarry lakes, the $\mathrm{EC}_{\mathrm{w}}$ value $\left(0.2-0.7 \mathrm{mS} \times \mathrm{cm}^{-1}\right)$ of water in Q1-G, Q2-TDG, Q3-G, and Q5-M quarry lakes indicates slight to moderate restrictions in using the water for irrigation, and as far as the water in the Q4-QS quarry lake $\left(<0.2 \mathrm{mS} \times \mathrm{cm}^{-1}\right)$ is concerned - to severe restrictions in using the water for irrigation.

The average value of the $\mathrm{BOD}_{5}$ indicator that reflects the load of organic contaminants in water, ranged from 1.32-2.04 $\mathrm{mgO}_{2} \times \mathrm{dm}^{-3}$ (Table 2, Fig. 2), where the highest concentrations were noted in the Q3-G quarry (average $2.04 \mathrm{mgO}_{2} \times \mathrm{dm}^{-3}$, $\max 4.1 \mathrm{mgO}_{2} \times \mathrm{dm}^{-3}$ ). These values were similar or even lower than those noted in natural lakes and artificial reservoirs (Przybyła et al., 2011, Wiatkowski et al., 2013), which indicated a small load of organic contaminants. High fluctuations and the highest $\mathrm{BOD}_{5}$ values in the Q3-G quarry may point to high productivity and eutrophication of its waters (Przybyła et al., 2011). The $\mathrm{BOD}_{5}$ value in the analysed quarry lakes did not exceed $12.0 \mathrm{mgO}_{2} \times \mathrm{dm}^{-3}$, so the water may be used for irrigation ( $\mathrm{PN}-84 / \mathrm{C}-04635)$.

In the Q2-TDG, Q3-G, Q4-QS, and Q5-M quarry lakes, the average nitrate content in water fell into the range of $0.30-0.84 \mathrm{mgNO}_{3} \times \mathrm{dm}^{-3}$ (Fig. 3), whereas in Q3-G, Q5-M, no nitrates were found in the spring of 2017 (Tab. 2), and the highest value was noted in Q2-TDG, $1.33 \mathrm{mgNO}_{3} \times \mathrm{dm}^{-3}$ (Table 2). On the other hand, in the flooded part of the Q1-G quarry, the nitrate content was, on the average, $33.48 \mathrm{mgNO}_{3} \times \mathrm{dm}^{-3}$ (range $31.72-34.51 \mathrm{mgNO}_{3} \times \mathrm{dm}^{-3}$ ), which was the highest value among the analysed quarry lakes (Table 2, Fig. 3). The nitrate content in the waters of the analysed quarry lakes was lower than that noted in mine lakes $\left(0.824-1.771 \mathrm{mgNO}_{3} \times \mathrm{dm}^{-3}\right)$ (Galas, 2003; Schultze et al., 2010, Jawecki and Mirski 2018), but it was similar to the load $\left(0.30-0.58 \mathrm{mgNO}_{3} \times \mathrm{dm}^{-3}\right)$ found in other quarry lakes in the Strzelin area (Jawecki and Mirski, 2018). Moreover, it was several times lower than in artificial water reservoirs $\left(1.7-26.0 \mathrm{mgNO}_{3} \times \mathrm{dm}^{-3}\right)$ (Brysiewicz et al., 2013, Siemieniuk et al., 2013, Wiatkowski et al., 2013), or natural lakes (0.44-32.27 $\mathrm{mgNO}_{3} \times \mathrm{dm}^{-3}$ ) (Przybyła et al., 2011). The load of nitrates in the waters of the Q-1G quarry lake differs significantly from the nitrate content in other quarry lakes analysed in this study, as well as from the test results in other quarry lakes in the Strzelin area (Jawecki and Mirski, 2018). The Q1-G quarry is an active mine, where excavation is conducted with use of explosive materials. The high load of nitrates in water may result from the leaching of residues of these explosives to water and surface and underground discharge from the arable lands surrounding the quarry (Ramstedt et al., 2003, Jawecki and Mirski, 2018). Considering the guidelines on the influence of nitrate load on the restrictions of usability of water for irrigation (Ayres and Wescot, 1985; Saha et al. 2015; Kaniszewski and Treder, 2018) it was found that the water from the Q2-TDG, Q3-G, Q4-QS, and Q5-M quarry lakes (Tab. 2) may be used without any restrictions $\left(<5 \mathrm{mgN}-\mathrm{NO}_{3} \times \mathrm{dm}^{-3}\right)$, while the water from Q1-G (Table 2) should be subject to slight to moderate restriction $\left(5-30 \mathrm{mgN}-\mathrm{NO}_{3} \times \mathrm{dm}^{-3}\right)$ if used for irrigation.

The average sulphate content in the waters of the analysed quarry lakes fluctuated in the range of $156.32-233.48 \mathrm{mgSO}_{4} \times \mathrm{dm}^{-3}$ (Fig. 3). The lowest measured value $\left(7.40 \mathrm{mgSO}_{4} \times \mathrm{dm}^{-3}\right)$ was found in the Q4-QS quarry (Tab. 2), while the highest value $\left(606.40 \mathrm{mgSO}_{4} \times \mathrm{dm}^{-3}\right)$ was measured in the Q1-G quarry (Table 2). The water in quarry lakes that emerged in the quarries of rock material ranged from $236-296 \mathrm{mgSO}_{4} \times \mathrm{dm}^{-3}$ (Galas, 2003; Kumar et al., 2009). In the pit (mine) lakes that emerged in mining pits of meta ores, the sulphate load ranged from approx. 140-400 $\mathrm{mgSO}_{4} \times \mathrm{dm}^{-3}, 780-2500 \mathrm{mgSO}_{4} \times \mathrm{dm}^{-3}$, even up to 7000-12500 $\mathrm{mgSO}_{4} \times \mathrm{dm}^{-3}$ (Ramstedt et al., 2003; Kumar et al., 2009). In pit (mine) lakes 

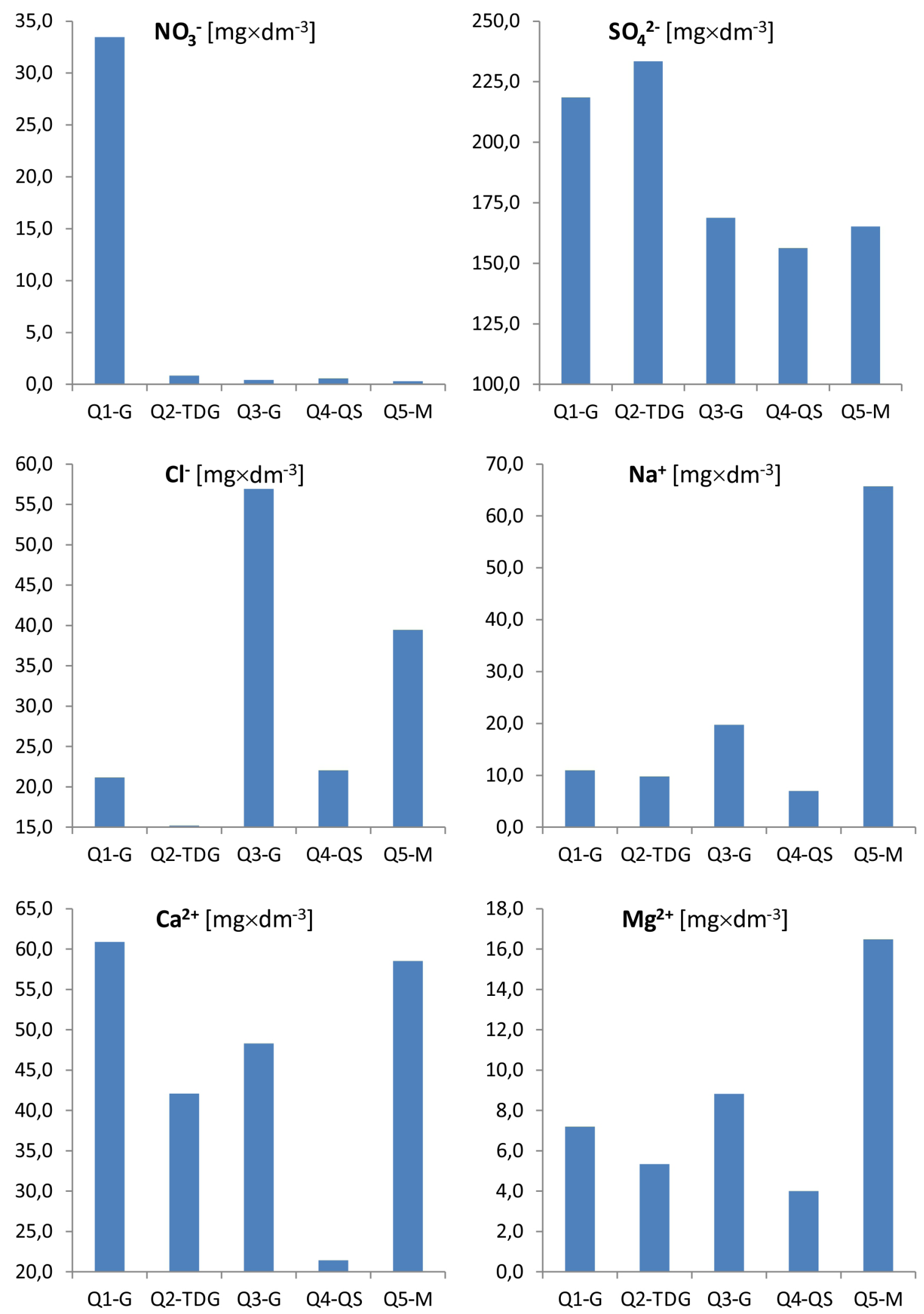

Fig. 3. Average concentration of selected ions in the water of the analysed quarry lakes in Strzelin area

emerging in open-cast lignite and coal pits (mines), the concentration of sulphides ranged from 30-100 $\mathrm{mgSO}_{4} \times \mathrm{dm}^{-3}$ (Kumar et al., 2009, Schultze et al., 2010), 230-770 (900) $\mathrm{mgSO}_{4} \times \mathrm{dm}^{-3}$ Kleeberg and Grüneberg, 2005; Denimal et al., 2005; Schultze et al., 2010; Kumar et al., 2016), 1800-2600 $\mathrm{mgSO}_{4} \times \mathrm{dm}^{-3}$ Kleeberg and Grüneberg, 2005; McCullough, 2008), reaching even up to 25000 
$\mathrm{mgSO}_{4} \times \mathrm{dm}^{-3}$ (Kumar et al., 2009). On the other hand, in natural lakes, the content of sulphates fell into a wide range of $0.7-186.4 \mathrm{mgSO}_{4} \times \mathrm{dm}^{-3}$ (Fiszer and Michałkiewicz, 1998; Ramstedt et al., 2003; Przybyła et al., 2011). The sulphate load in the waters of the analysed quarry lakes is similar to the values noted in natural lakes and in the quarry lakes that emerged in quarries. It is also significantly lower than the sulphate content in the waters of acidic lakes that emerged in coal (especially lignite) mining pits. Considering the average value of sulphate content, the water meets the requirements for irrigation. However, the maximum values noted in April 2017 exceed the acceptable value of $400 \mathrm{mgSO}_{4} \times \mathrm{dm}^{-3}$ (PN-84/C-04635).

The average chloride content in the analysed quarry lakes ranged from 15.20 to $56.92 \mathrm{mgCl} \times \mathrm{dm}^{-3}$ (Fig. 3). The highest values, in the range $47.60-60.40 \mathrm{mgCl} \times \mathrm{dm}^{-3}$ were noted in the Q3-G quarry (Table 2), while the lowest, in the range $13.40-16.60 \mathrm{mgCl} \times \mathrm{dm}^{-3}-$ in the Q2-TGD quarry (Table 2). In the Polish natural lakes, this value ranges from $70-100 \mathrm{mgCl} \times \mathrm{dm}^{-3}$ (Fiszer and Michałkiewicz, 1998; Przybyła et al., 2011). In a limestone quarry, lake it was approx. $175 \mathrm{mgCl} \times \mathrm{dm}^{-3}$ (Galas, 2003). In the lakes that emerged in metal ore excavation pits, the chloride content ranged from approx. $2.2-2.8 \mathrm{mgCl} \times \mathrm{dm}^{-3}$ (Ramstedt et al., 2003), in lignite pit (mine) lakes from $0-100 \mathrm{mgCl} \times \mathrm{dm}^{-3}$ (Schultze et al., 2010), and in coal pit (mine) lakes it was approx. 780-880 mgCl $\times \mathrm{dm}^{-3}$ (Kumar et al., 2016). The chloride load noted in the waters of the analysed quarry lakes is below 400 (300 for drop irrigation) $\mathrm{mgCl} \times \mathrm{dm}^{-3}$, so the water meets the requirements for irrigation use (PN-84/C-04635; Kaniszewski and Treder, 2018). It is also lower than 140 (100 for drop irrigation) $\mathrm{mgCl} \times \mathrm{dm}^{-3}$; thus, pursuant to the FAO guidelines, there are no restrictions on using it for irrigation (Ayers and Westcott, 1985; Saha et al. 2015).

The average sodium content in the waters of the analysed quarry lakes ranged from 6.98-65.72 $\mathrm{mgNa} \times \mathrm{dm}^{-3}$ (Fig. 3, Table 2) where the highest values, in the range 55.90-85.00 $\mathrm{mgNa} \times \mathrm{dm}^{-3}$ were noted in the Q5-M quarry, and the lowest $\left(5.8-7.60 \mathrm{mgNa} \times \mathrm{dm}^{-3}\right)$ in the Q4-QS quarry (Table 2). The sodium ion content in the Q1-G, Q2-TDG, and Q4-QS quarry lakes was similar to the average load (10-11 $\mathrm{mgNa} \times \mathrm{dm}^{-3}$ ) in natural Polish lakes (Kajak, 2001). In Q3-G and Q5-M, it was close to the sodium concentrations $\left(\sim 21.0-60.0 \mathrm{mgNa} \times \mathrm{dm}^{-3}\right)$ noted in old quarry lakes and quarry ponds (Orzepowski and Pulikowski, 2008), and retention reservoirs $\left(\sim 45-55 \mathrm{mgNa} \mathrm{dm}^{-3}\right)$ that are a source of water for irrigation (Ravikumar et.al., 2013). At the same time, the sodium content was significantly lower than in certain lakes $\left(\sim 138-178 \mathrm{mgNa} \times \mathrm{dm}^{-3}\right)$ used for irrigation (Ravikumar et al., 2013), as well as that in coal pit (mine) lakes $\sim 450 \mathrm{mgNa} \times \mathrm{dm}^{-3}(\mathrm{Ku}-$ mar et al., 2016). Although the sodium load in the water of the analysed quarry lakes is relatively low, its application for surface irrigation will be subject to strict restrictions (slight to moderate restrictions only in the case of Q4-QS), although it may be used without any limitations for sprinkler irrigation (Ayers and Westcott, 1985, Saha et al. 2015). The sodium load in the water from the analysed lakes is lower than $140 \mathrm{mgNa} \times \mathrm{dm}^{-3}$ so it meets the requirements of PN-84/C-04635. According to the guidelines provided in the work by Kaniszewski and Treder (2018), only the water from the Q5-M lake will be subject to small or medium restrictions (range 50-100 $\mathrm{mgNa} \times \mathrm{dm}^{-3}$ ) when used for irrigation. The sodium ion content was also used to determine the SAR index discussed above.

In the waters of the analysed quarry lakes, the mean calcium content fell into the range of 21.44-60.90 mgCa $\times \mathrm{dm}^{-3}$ (Fig. 3, Tab. 2). The

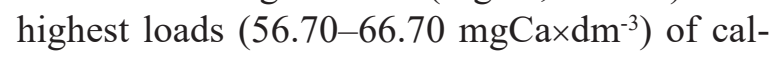
cium were noted in Q1-G, while the lowest ones (19.60-22.40 mgCa× $\mathrm{dm}^{-3}$ ) in Q4-QS (Tab. 2). The quarry lakes in Strzelin area have poor calcium content (Jawecki and Mirski, 2018). Apart from Q4-QS (the lowest calcium load), the calcium concentrations noted in the remaining quarry lakes were close to the bottom values ( 50.0-124.0 $\left.\mathrm{mgCa} \times \mathrm{dm}^{-3}\right)$ noted in the natural lakes in Poland (Fiszer and Michałkiewicz, 1998; Przybyła et al., 2011, Potasznik and Szymczyk, 2015), and to the lower range of calcium load $(\sim 50-180$ $\left.\mathrm{mgCa} \times \mathrm{dm}^{-3}\right)$ noted in other quarry lakes or quarry pounds (Galas, 2003; Orzepowski and Pulikowski, 2008; Kumar et al. 2009) and similar to the calcium loads $\left(\sim 15-37 \mathrm{mgCa} \times \mathrm{dm}^{-3}\right)$ in a retention reservoir used for irrigation (Ravikumar et al., 2013). However, they were significantly lower than the concentrations $\left(\sim 132-161 \mathrm{mgCa}^{-3} \mathrm{dm}^{-3}\right)$ in a natural lake used for irrigation (Ravikumar et al., 2013). In some coal pit (mine) lakes (Kumar et al. 2009; Kumar et al. 2016) the calcium loads $\left(\sim 6.0-35.0 \mathrm{mgCa} \mathrm{dm}^{-3}\right)$ were lower than in the analysed Strzelin quarry lakes, but in part of the coal and lignite pit (mine) lakes, the calcium loads 
were significantly higher $\sim 100-500 \mathrm{mgCa} \times \mathrm{dm}^{-3}$ (Kumar et al., 2009; Schultze et al., 2010). On the other hand, in the pit (mine) lakes that emerged in metal ore excavation pits, the calcium load fell into the range of approx. $\sim 330-1120 \mathrm{mgCa}^{-3} \mathrm{dm}^{-3}(\mathrm{Ku}-$ mar et al., 2009). The calcium ion content was also used to determine the SAR index discussed above.

The average magnesium content in the analysed quarry lake waters fell into the range of 4.00-16.48 Mg $\times \mathrm{dm}^{-3}$ (Fig. 3, Table 2). The highest loads $\left(15.40-17.40 \mathrm{mgMg} \times \mathrm{dm}^{-3}\right)$ were noted in Q5-M, and the lowest (3.60-4.20 ${\left.\mathrm{mgMg} \times \mathrm{dm}^{-3}\right)}^{-3}$ in Q4-QS (Table 2). The magnesium load in the quarry lakes in Strzelin area was similar to the low and medium ranges $\left(\sim 9.5-40.0 \mathrm{mgMg} \times \mathrm{dm}^{-3}\right)$ of magnesium concentration noted in Polish natural lakes (Fiszer, Michałkiewicz, 1998; Przybyła et al., 2011; Potasznik and Szymczyk, $2015)$, and below the lower range of magnesium load $\left(\sim 20-58 \mathrm{mgMg} \times \mathrm{dm}^{-3}\right)$ noted in other quarry lakes or quarry pounds (Galas, 2003; Orzepowski and Pulikowski, 2008; Kumar et al. 2009). It was similar or lower than the magnesium content in a retention reservoir $(\sim 14-20$ $\left.\mathrm{mgMg} \times \mathrm{dm}^{-3}\right)$, but lower than in a natural lake $\left(\sim 24-45 \mathrm{mgMg} \times \mathrm{dm}^{-3}\right)$, used for irrigation (Ravikumar et al. 2013). The magnesium load in the analysed quarry lakes in the Strzelin area was lower or similar to the lowest values noted in certain coal and lignite pit (mine) lakes ( $\sim 10-200$ (2240) $\mathrm{mgMg} \times \mathrm{dm}^{-3}$ ) and significantly lower than the highest, maximum values (Kumar et al. 2009; Schultze et al., 2010; Kumar et al., 2016). On the other hand, in the pit (mine) lakes that emerged in metal ore excavation pits, the magnesium load fell into the range of approx. 860-1240 (3150) $\mathrm{mgMg} \times \mathrm{dm}^{-3}$ (Kumar et al., 2009), which was even several hundred times higher than in the analysed Strzelin quarry lakes. The magnesium ion content was also used to determine the SAR index discussed above.

The average iron content in the samples of water from the analysed quarry lakes fell into the range of $0.002-0.078 \mathrm{mg} \mathrm{Fe} \times \mathrm{dm}^{-3}$ (Table 2). The highest value $\left(0.210 \mathrm{mg} \mathrm{Fe} \times \mathrm{dm}^{-3}\right)$ was noted in the Q2-TDG quarry lake. In 36\% of the analysed samples, no iron was found. In the Q3-G quarry, iron was not detected in 4 analysed samples, while in Q4-QS, iron was present in all the collected samples. Similar values $\left(0.016-0.5 \mathrm{mg} \mathrm{Fe} \times \mathrm{dm}^{-3}\right)$ were noted in lakes (Kleeberg and Grüneberg, 2005; Przybyła et al., 2011; Gwoździński et al., 2014), although in some cases, the iron loads
(3.93-49.0 $\left.\mathrm{mg} \mathrm{Fe} \times \mathrm{dm}^{-3}\right)$ in lake waters were decidedly higher (Kleeberg and Grüneberg, 2005; Elzwayie et al., 2017), similarly as in water reservoirs $0.062-12.0 \mathrm{mg} \mathrm{Fe} \times \mathrm{dm}^{-3}$ (Avila-Pérez et al., 1999; Karadede and Ünlü, 2000). On the other hand, in silica sand quarry lake, the iron concentration was $0.14 \mathrm{mg} \mathrm{Fe} \times \mathrm{dm}^{-3}$ (Kumar et al., 2009), and in quartzite and quarzitic sandstone quarry lakes, it fell into the range of 5.2-23.3 (max.-860) $\mathrm{mg} \mathrm{Fe} \times \mathrm{dm}^{-3}$ (Migaszewski et al., 2016), which was significantly higher than in the analysed quarry lakes. The iron content in the analysed Strzelin quarry lakes was similar to

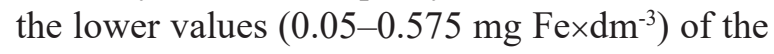
iron load in the quarry lakes that emerged in metal ore mines (Kumar et al., 2009), where these values often reached up to $2.5-3.23 \mathrm{mg} \mathrm{Fe} \times \mathrm{dm}^{-3}$, and even $248 \mathrm{mg} \mathrm{Fe} \times \mathrm{dm}^{-3}$ (Ramstedt et. al., 2003; Kumar et al., 2009). The iron load noted in the analysed

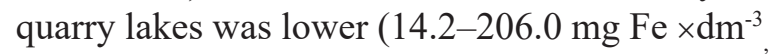

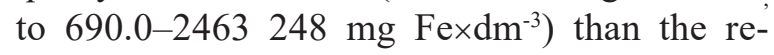
sults obtained for coal and lignite quarry lakes (Kleeberg, Grüneberg, 2005; McCullough, 2008; Kumar et al., 2009) although in certain lakes, these values were comparable (0.003-1.1 $\left.\mathrm{mg} \mathrm{Fe} \times \mathrm{dm}^{-3}\right)$ to those noted in the Strzelin quarry lakes (Kleeberg and Grüneberg, 2005; Kumar et al., 2009; Schultze et al., 2010; Hinwood et al., 2012; Kumar et al., 2016). The iron content in the analysed water was below $10.0 \mathrm{mg} \mathrm{Fe} \times \mathrm{dm}^{-3}\left(5.0{\mathrm{mg} \mathrm{Fe} \times \mathrm{dm}^{-3}}^{-3}\right.$ by FAO), so it did not lead to any restrictions concerning the use of water from the analysed quarry lakes for irrigation, and the load below $0.1 \mathrm{mg}$ Fe $\times \mathrm{dm}^{-3}$ leads to the restrictions in sprinkler irrigation due to the risk of sprinkler clogging (Ayers and Westcott, 1985; PN-84/C-04635, Kaniszewski and Treder, 2018).

The average manganese content in the analysed quarry lakes in the Strzelin area falls into the range of 0.008-0.090 mg Mn $\times \mathrm{dm}^{-3}$ (Table 2). The highest values were noted in Q3-G and Q5-M, -0.370 and $0.310 \mathrm{mg} \mathrm{Mn} \times \mathrm{dm}^{-3}$, respectively (Tab. 2). In the summer of 2017, the presence of manganese was not detected in any of the quarry lakes. The manganese load in the analysed waters was similar to that (0.007-0.200 (1.32) $\mathrm{mg} \mathrm{Mn} \times \mathrm{dm}^{-3}$ ) noted in lakes (Gwoździński et al., 2014; Elzwayie et al., 2017). Higher manganese concentrations

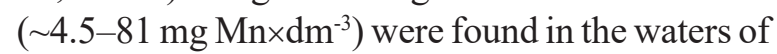
the quarry lakes emerging in metal ore mining pits (Ramstedt et. al., 2003; Kumar et al., 2009). On the other hand, in the pit (mine) lakes that emerged in coal and lignite mines the manganese load 
falls into the range of $0.0002-1.8 \mathrm{mg} \mathrm{Mn} \times \mathrm{dm}^{-3}$,

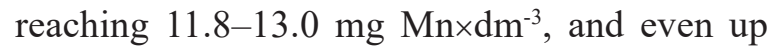
to $150.0 \mathrm{mg} \mathrm{Mn} \times \mathrm{dm}^{-3}$ (Stottmeister et al., 1999; Kumar et al., 2009; Schultze et al., 2010; Hinwood et al., 2012), and the values over $0.5 \mathrm{mg} \mathrm{Mn} \times \mathrm{dm}^{-3}$ significantly exceed those noted in the analysed Strzelin quarry lakes. In the silica sand quarry lake, the manganese content was $<0.01 \mathrm{mg} \mathrm{Mn} \times \mathrm{dm}^{-3}$ (Kumar et al., 2009), which was similar to the values from the analysed quarry lakes. In quartzite and quarzitic sandstone quarry lakes, it fell into the range of 1.062- 6.317 $\mathrm{mg} \mathrm{Mn} \times \mathrm{dm}^{-3}$ (Migaszewski et al., 2016), which was higher than in the analysed quarry lakes. The manganese load in the analysed water was lower than $0.8 \mathrm{mg} \mathrm{Mn} \times \mathrm{dm}^{-3}$ ( $0.2 \mathrm{mg} \mathrm{Mn} \times \mathrm{dm}^{-3}$ by FAO) so it did not lead to any restrictions on using the water from the analysed quarry lakes for irrigation. The content below $0.1 \mathrm{mg} \mathrm{Mn} \times \mathrm{dm}^{-3}$ means that there are no restrictions concerning its use in sprinkler irrigation, either, as the risk of clogging the sprinkler is low (Ayers and Westcott, 1985; PN-84/C-04635, Kaniszewski and Treder, 2018).

\section{CONCLUSIONS}

The analysed quarry lakes that emerged as a result of flooding closed quarries have relatively small surface areas (0.89-3.60 ha) and are relatively deep (10-25 (max. 40) $\mathrm{m}$ ). The values of the analysed water quality indicators are rather low and similar to the parameters of natural lakes. At the same time, water pollution is decidedly lower than in most pit (mine) lakes, in particular acidic AML. The reservoirs that emerged in marble quarry (Q5-M), and quartzite schist (Q4-QS), stand out among the analysed quarry lakes. Q5-M was characterised by quite high values of the ECw, SAR, and TDS indicators, as well as of $\mathrm{Na}, \mathrm{Ca}$, and $\mathrm{Mg}$, which probably results from erosion and leaching of calcium and magnesium compounds from marble. The lowest values of the analysed parameters were noted in Q4-QS. The lake is situated in a quarry that is periodically operated and quite regularly drained. It is characterised by high water level fluctuations. This quarry lake is supplied mainly by the rainwater surface runoff from the direct catchment of the quarry, which does not carry

Table 3. Evaluation of the usability of quarry lake water for irrigation purposes

\begin{tabular}{|c|c|c|c|c|c|c|c|c|c|c|c|}
\hline \multirow{2}{*}{\multicolumn{2}{|c|}{ Parameter }} & \multicolumn{2}{|c|}{ Q1-G } & \multicolumn{2}{|c|}{ Q2-TDG } & \multicolumn{2}{|c|}{ Q3-G } & \multicolumn{2}{|c|}{ Q4-QS } & \multicolumn{2}{|c|}{ Q5-M } \\
\hline & & $P L$ & $F A O$ & $P L$ & $F A O$ & $P L$ & $F A O$ & $P L$ & $F A O$ & $P L$ & $F A O$ \\
\hline \multicolumn{2}{|c|}{$\mathrm{pH}^{2,3}$} & $\mathrm{DH}$ & $\mathrm{DH}$ & DM & DM & $\mathrm{DM}$ & DM & DM & DM & $\mathrm{DM}$ & $\mathrm{DM}$ \\
\hline \multicolumn{2}{|c|}{$\mathrm{EC}_{\mathrm{w}}{ }^{1,3.4}$} & $\mathrm{DL}$ & $\mathrm{DL}$ & $\mathrm{DL}$ & $\mathrm{DL}$ & DL & $\mathrm{DL}$ & $\mathrm{DL}$ & $\mathrm{DL}$ & $\mathrm{DL}$ & $\mathrm{DL}$ \\
\hline \multicolumn{2}{|c|}{$\mathrm{SAR}^{4}$} & & SH-L & & SH-L & & SH-L & & $\mathrm{SH}-\mathrm{L}$ & & $\mathrm{SH}-\mathrm{L}$ \\
\hline \multicolumn{12}{|c|}{$\mathrm{SAR} / \mathrm{EC}_{\mathrm{w}}{ }^{3.4}$} \\
\hline \multicolumn{12}{|c|}{ TDS ${ }^{13.4}$} \\
\hline \multicolumn{12}{|c|}{$\mathrm{BOD}_{5}{ }^{2}$} \\
\hline \multicolumn{12}{|c|}{ Nitrates ${ }^{3.4}$} \\
\hline \multicolumn{12}{|c|}{ Sulphates $^{2}$} \\
\hline \multicolumn{12}{|c|}{ Chlorides ${ }^{1.2 .3 .4}$} \\
\hline \multirow{2}{*}{ Sodium ${ }^{1.2 .3 .4}$} & SU.I & & & & & & & & & & \\
\hline & SP.I & & & & & & & & & & \\
\hline \multicolumn{2}{|c|}{ Manganese $^{2}$} & $\mathrm{DL}$ & $\mathrm{DL}$ & $\mathrm{DL}$ & $\mathrm{DL}$ & $\mathrm{DL}$ & $\mathrm{DL}$ & $\mathrm{DL}$ & $\mathrm{DL}$ & $\mathrm{DL}$ & DL \\
\hline \multicolumn{2}{|c|}{$\operatorname{Iron}^{2}$} & $\mathrm{DL}$ & $\mathrm{DL}$ & $\mathrm{DL}$ & $\mathrm{DL}$ & $\mathrm{DL}$ & $\mathrm{DL}$ & $\mathrm{DL}$ & $\mathrm{DL}$ & $\mathrm{DL}$ & $\mathrm{DL}$ \\
\hline \multicolumn{5}{|c|}{ Reference standard PN-84/C-04635 } & \multicolumn{2}{|c|}{ Met } & \multicolumn{2}{|c|}{ Not met } & \multicolumn{3}{|c|}{ No guidelines } \\
\hline \multicolumn{5}{|c|}{ Degree of restriction on use water to irrigation } & None & \multicolumn{2}{|c|}{ Slight to moderate } & & & \multicolumn{2}{|c|}{ No guidelines } \\
\hline \multicolumn{12}{|c|}{$\begin{array}{l}P L-{ }^{1} \text { Kaniszewski and Treder, } 2018 \text { or }{ }^{2} \mathrm{PN}-84 / \mathrm{C}-04635 . F A O-{ }^{3} \text { Ayers and Westcott, } 1985 \text { or }{ }^{4} \text { Saha et al. } 2015 \\
\text { SU.I - Surface irrigation, SP.I - Sprinkler irrigation } \\
\text { SH-L - low, SH-M - medium, SH-H- high, SH-VH - very high - the sodium hazard of irrigation water based on SAR (Saha et } \\
\text { al. 2015). } \\
\text { SAR/EC }{ }_{w} \text { - assessment of sodium hazard of irrigation water based on SAR and EC }{ }_{w} \text { (Ayers and Westcott, 1985; Saha et al. } \\
\text { 2015) } \\
\text { DL -low, DM - medium, DH- high - restricted use for sprinkler irrigation due to probability of sprinkler clogging (Saha et al. } \\
\text { 2015; Kaniszewski and Treder, 2018). }\end{array}$} \\
\hline
\end{tabular}


a high load of pollutants. The highest concentration of nitrates that were noted in the quarry lake in the Q1-G active quarry was probably caused by leaching of residue of explosive materials from the pit and by runoff from the surrounding fields. On the other hand, the highest $\mathrm{BOD}_{5}$ values that were noted in the Q3-G quarry lake were most likely caused by pressure from wastewater from farms and rainwater surface runoff, as it was described in the study by Jawecki and Mirski (2018).

Most of the indicators in the analysed quarry lakes met the requirements on using water for irrigation provided in Polish and international guidelines (Tab. 3). Due to high $\mathrm{pH}$ value, the water from the Q1-G quarry lake did not meet the requirements provided in $\mathrm{PN}-84 / \mathrm{C}-04635$. Due to the increased nitrate content in Q1-G, excessive sodium concentration and the value of $\mathrm{EC}_{\mathrm{w}}$ in Q5-M (Kaniszewski and Treder, 2018), the water from these quarry lakes should be subject to slight to moderate restriction on use water to irrigation. According to the FAO Guidelines (Ayers and Westcott, 1985; Saha et al. 2015) the assessment of sodium hazard of irrigation water based on SAR and $\mathrm{EC}_{\mathrm{w}}$ suggests severe restrictions in using the water from Q4-QS for irrigation and slight to moderate restriction in using the water from the remaining quarry lakes for irrigation. Due to high sodium content, severe restrictions on using the water from all quarry lakes for surface irrigation should be applied. As a result of high $\mathrm{pH}$, the water from Q1-G is subject to high restrictions on use for sprinkler irrigation and the water from Q2-TDG, Q3-G, Q4-QS, and Q5-M should be subject to moderate restrictions on use for sprinkler irrigation.

The conducted research allowed the authors to formulate the following conclusions:

1. The water quality indicators in the quarry lakes presented in this study are similar or lower than those in natural lakes.

2. The content of nitrates and sodium, water $\mathrm{pH}$ and sodium hazard of irrigation water based on SAR and $\mathrm{EC}_{\mathrm{w}}$ requires slight to moderate and severe restrictions on using the water from Q1-G for irrigation, in particular surface irrigation.

3. The content of sodium, electrical conductivity $\left(\mathrm{EC}_{\mathrm{w}}\right)$ and $\mathrm{pH}$ of water, sodium hazard of irrigation water based on SAR and $\mathrm{ECW}$ requires slight to moderate and severe restrictions on using the water from Q5-M for irrigation, in particular surface irrigation.
4. The water from the Q2-TDG, Q3-G, Q4-QS quarry lakes meets the requirements of Polish reference standards, so it may be used for irrigation without any restrictions, while the water from Q5-M should be subject to slight to moderate restriction on use due to increased $\mathrm{EC}_{\mathrm{w}}$, and sodium concentration.

5. Due to the sodium content, the water from all analysed quarry lakes, was assessed pursuant to the guidelines of FAO as subject to severe restrictions on using for surface irrigation, whereas the assessment of sodium hazard of irrigation water based on SAR and $\mathrm{EC}_{\mathrm{w}}$ points to severe restrictions on using the water from Q4-QS for irrigation and water from the other quarry lakes should be subject to slight to moderate restrictions.

6. Electrical conductivity $\left(\mathrm{EC}_{\mathrm{w}}\right)$, as well as the manganese and iron content indicate that the water may potentially be used for sprinkler irrigation, although the increased $\mathrm{pH}$ may point to moderate (Q2-TDG, Q3-G, Q4-QS) and high (Q1-G) probability of sprinkler clogging.

\section{REFERENCES}

1. Avila-Pérez P., Balcázar M., Zarazúa-Ortega G., Barceló-Quintal I., Díaz-Delgado C. 1999. Heavy metal concentrations in water and bottom sediments of a Mexican reservoir. Science of the Total Environment, 234 (1-3), 185-196.

2. Axler R., Yokom S., Tikkanen C., McDonald M., Runke H., Wilcox D., Cady B. 1998. Restoration of a Mine Pit Lake from Aquacultural Nutrient Enrichment. Restoration Ecology, 6(1), 1-19. DOI: 10.1046/j.1526-100x.1998.00612.x.

3. Ayers R.S. and Westcott D.W. 1985. Water quality for agriculture, FAO irrigation and drainage paper 29. Rev. 1. Food and Agriculture Organization of the United Nations, Rome.

4. Bauder, J. W., Bauder, T.A., Waskom, R. M., Scherer, T. F. 2010. Assessing the suitability of water (quality) for irrigation - salinity and sodium. Retrieved from Northern Plains and Mountains Regional Water Program. http://region8water.colostate.edu/ PDFs/Assessing\%20the\%20Suitablity \%20of \%20 Water\%20Quality\%20for\%20Irrigation.pdf(access of the 2019-07-18).

5. Brysiewicz A., Wesołowski P., Rawicki K. 2013. Porównanie stężenia składników chemicznych w wodzie ze śródpolnego oczka wodnego oraz w wodzie gruntowej z przylegających terenów rolniczych. Woda-Środowisko-Obszary Wiejskie, 13, 2(42), 17-31. 
6. Castendyk D.N., Mauk J.L., Webster J.G. 2005. A mineral quantification method for wall rocks at open pit mines, and application to the Martha $\mathrm{Au}-\mathrm{Ag}$ mine, Waihi, New Zealand. Applied Geochemistry, 20, 135-156.

7. Chudzik W. 2012. The process of mined land reclamation in natural aggregate quarries exemplified by the sand and gravel quarry Dębina Łętowska. AGH Journal of Mining and Geoengineering, 36(1), 89-96.

8. Czerniawska-Kusza I., Brożonowicz A. 2014. Zoobenthos in post-exploitation reservoirs of marls and limestone in Opole Silesia. Polish Journal of Natural Sciences, 29(4), 307-318.

9. De Luca D.A,, Castagna S., Lasagna M. 2013. Hydrogeological features conditioning trophic levels of quarry lakes in western Po plain (northwestern Italy), Geophysical Research Abstracts, 15, GU2013-8085.

10. Denimal S., Bertrand C., Mudry J., Paquette Y., Hochart M., Steinmann M. 2005. Evolution of the aqueous geochemistry of mine pit lakes -BlanzyMontceau-les-Mines coal basin (Massif Central, France): origin of sulfate contents, effects of stratification on water quality. Applied Geochemistry, 20, 825-839.

11. Domashenko Y., and Vasilyev, S. 2018. Agroecological Substantiation for the Use of Treated Wastewater for Irrigation of Agricultural Land. Journal of Ecological Engineering, 19(1), 48-54. https://doi. org/10.12911/22998993/79567.

12. Doupé R.G., Lymbery A.J. 2005. Environmental risks associated with beneficial end uses of mine lakes in Southwestern Australia. Mine Water and the Environment, 24(3), 134-138.

13. Doyle, G.A., Runnells D.D. 1997. Physical limnology of existing mine pit lakes. Mining Engineering, 49, 76-80.

14. EEA Report No 2/2009. Water resources across Europe - confronting water scarcity and drought. Luxembourg: Office for Official Publications of the European Communities, 2009. DOI 10.2800/16803.

15. Elzwayie A., Afan, H.A., Allawi, M.F., El-Shafie A. 2017. Heavy metal monitoring, analysis and prediction in lakes and rivers: state of the art. Environ Sci Pollut Res, 24.12104-12117. DOI 10.1007/ s11356-017-8715-0.

16. Fiszer M., Michałkiewicz M. 1998. Ocena stanu zanieczyszczenia Jeziora Lednica na podstawie badań fizyko-chemicznych epilimnionu, hypolimnionu. Studia Lednickie 5, 269-282.

17. Galas J. 2003. Limnological Study on a Lake Formed in a Limestone Quarry (Kraków, Poland). I. Water Chemistry. Polish Journal of Environmental Studies, 12(3), 297-300.
18. Grünewald U. 2001. Water resources management in river catchments influenced by lignite mining. Ecological Engineering, 17.143-152.

19. GUS 2015: Ochrona Środowiska 2015, Warszawa 2015.

20. Gwoździński K., Mazur J., Pieniążek A. 2014. Concentrations of metals in water of unmonitored lakes near a landscape park. Pol. J. Environ. Stud. 23(4), 1317-1321.

21. Hinwood A.L., Heyworth J., Tanner H., McCullough C. 2012. Recreational use of acidic pit lakes-human health considerations for post closure planning. Journal of Water Resource and Protection, 2012, 4, 1061-1070.

22. Hobot A. (Ed.) 2014. Aktualizacja wykazu JCWP, SCWP dla potrzeb kolejnej aktualizacji planów w latach 2015-2021 wraz z weryfikacją typów wód części wód - ETAP, - Metodyka. KZGW, Gliwice-Warszwa.

23. Jawecki B. 2017. Rola kamieniołomów w kształtowaniu krajobrazu na przykładzie ziemi strzelińskiej. Monografia. Uniwersytet Przyrodniczywe Wrocławiu

24. Jawecki B., Dąbek P.B., Pawęska K., Wei X. 2018. Estimating Water Retention in Post-mining Excavations Using LiDAR ALS Data for the Strzelin Quarry, in Lower Silesia. Mine Water and the Environment, (Online) https://doi.org/10.1007/ s10230-018-0526-0.

25. Jawecki B., Mirski J. 2018. Wstępna ocena zawartości biogenów w wodach zalanych nieczynnych kamieniołomów położonych na terenach wiejskich (Preliminary evaluation of nutrients concentration in quarry lakes located on the rural areas). Inżynieria Ekologiczna, (Ecological Engineering) 19(6), 1-13, https://doi.org/10.12912/23920629/94957.

26. Kajak Z. 2001. Hydrobiologia-limnologia. Ekosystemy wód śródlądowych.: Wydawnictwo Naukowe PWN. Warszawa.

27. Karadede H., Ünlü E. 2000. Concentrations of some heavy metals in water, sediment and species from the Atatürk Dam Lake (Euphrates), Turkey. Chemosphere, 41.1371-1376.

28. Klapper H., Geller W. 2001. Water quality management of mining lakes - a new field of applied hydrobiology. Acta hydrochim. hydrobiol. 29 (6-7), 363-374.

29. Kleeberg A., Grüneberg B. 2005. Phosphorus mobility in sediments of acid mining lakes, Lusatia, Germany. Ecological Engineering, 24, 89-100.

30. Kołodziejczyk U. 2009. Hydrological, geological and geochemical conditions determining reclamation of post - mine land in the region of Łęknica. Gospodarka Surowcami Mineralnymi, Tom 25, Zeszyt 3. 2009, 190-201. 
31. Kumar N.R., McCullough C.D. Lund M.A., Larranaga S.A. 2016. Assessment of factors limiting algal growth in acidic pit lakes - a case study from Western Australia, Australia. Environmental Science and Pollution Research, 23, 5915-5924. DOI 10.1007/s11356-015-5829-0.

32. Kumar R. N., McCullough C. D., Lund M. A. 2009. Water Resources in Australian Mine Pit Lakes. Mining Technology, 118(3-4), 204-211. DOI:10.1179/ $174328610 X 12682159815028$.

33. Lykhovyd, P.V., Lavrenko, S., Lavrenko, N., Dementiieva, O. 2019. Agro-environmental evaluation of irrigation water from different sources, together with drainage and escape water of rice irrigation systems, according to its impact on maize. Journal of Ecological Engineering, 20(2), 1-7. https://doi. org/10.12911/22998993/94916.

34. Łabędzki L. 2016. Actions and measures for mitigation drought and water scarcity in agriculture. Journal of Water and Land Development, 29(IV-VI), 3-10. DOI: 10.1515/jwld-2016-0007.

35. Mayne C.D. 1994. The Limnology of Three Limestone Rock Quarries in East-Central Nebraska and Western Iowa. Transactions of the Nebraska Academy of Sciences, 21, 1-7.

36. McCullough C.D. 2008. Approaches to remediation of acid mine drainage water in pit lakes. International Journal of Mining, Reclamation and Environment, 22(2), 105-119.

37. McCullough C.D., Lund M.A. 2006. Opportunities for sustainable mining pit lakes in Australia. Mine Water and the Environment, 25, 220-226.

38. Migaszewski Z.M., Gałuszka A., Dołęgowska S. 2016. Rare earth and trace element signatures for assessing an impact of rock mining and processing on the environment: Wiśniówka case study, south-central Poland. Environ Sci Pollut Res, 23, 24943-24959, DOI 10.1007/s11356-016-7713-y.

39. Molenda T. 2006. Górnicze środowiska akwatyczne - obiekty obserwacji procesów hydrologicznobiologicznych. Prace Naukowe Instytutu Górnictwa Politechniki Wrocławskiej, 117(32), 239-250.

40. Nixdorf B., Lessmann D., Deneke R. 2005. Mining lakes in a disturbed landscape: Application of the EC Water Framework Directive and future management strategies. Ecological Engineering, 24, 67-73.

41. Orzepowski W., Pulikowski K. 2008. Magnesium, calcium, potassium and sodium content in groundwater and surface water in arable lands in the commune of Kąty Wrocławskie. J. Elementol., 13(4), 605-614.

42. Patro M., Zubala T. 2012. Possibilities of shaping the water retention in agricultural landscape. Teka Kom. Ochr. Kszt. Środ. Przyr. - OL PAN, 9, 143-152.
43. PN-84/C-04635. Woda do nawadniania roślin na użytkach rolnych oraz do ich opryskiwania chemicznymi środkami ochrony roślin.

44. Potasznik A., Szymczyk S. 2015. Magnesium and calcium concentrations in the surface water and bottom deposits of a river-lake system. J. Elem., 20(3), 677-692. DOI: 10.5601/jelem.2015.20.1.788.

45. Przybyła C., Zbierska Z., Dwornikowska Ż. 2011. Ocena zmian jakości wody w wybranych jeziorach

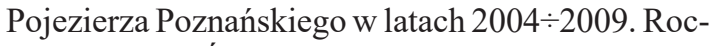
znik Ochrona Środowiska, 13, 723-746.

46. Puczyńska I., Skrzypski J. 2009. Integracja działań biologicznych, technicznych jako podstawa intensyfikacji procesów samooczyszczania się zbiorników zaporowych (na przykładzie Zbiornika Sulejowskiego). Ecological Chemistry and Engineering S, 16(S2), 221-235.

47. Ramstedt M., Carlsson E., Lövgren L. 2003. Aqueous geochemistry in the Udden pit lake, northern Sweden. Applied Geochemistry, 18, 97-108.

48. Rauba M, Dembowska D. 2018. Ocena stężeń związków azotu, fosforu w wodach środkowego basenu rzeki Biebrza, Inżynieria Ekologiczna, 19(3), 62-68. https://doi.org/10.12912/23920629/86054.

49. Ravazzani, G., Giudici, I., Schmidt, C., and Mancini, M. 2011. Evaluating the Potential of Quarry Lakes for Supplemental Irrigation. Journal of Irrigation and Drainage Engineering 137(80), 564-571. DOI. 10.1061/(ASCE)IR.1943-4774.0000321.

50. Ravikumar P., Aneesul Mehmood M., Somashekar R.K. 2013. Water quality index to determine the surface water quality of Sankey tank and Mallathahalli lake, Bangalore urban district, Karnataka, India. Appl Water Sci 3:247-261, DOI 10.1007/ s13201-013-0077-2.

51. Saha U., ButcherS., Porter W., Sonon L., Hawkins G., Lessl J. 2015. Irrigation Water Quality for Agriculture. UGA Extension Bulletin 1448.

52. Schultze M., Pokrandt K-H., Hille W. 2010. Pit lakes of the Central German lignite mining district: Creation, morphometry and water quality aspects. Limnologica, 40(2), 148-155. http://dx.doi. org/10.1016/j.limno.2009.11.006.

53. Siemieniuk A. Szczykowska J., Wiater J. 2013. Sezonowe zmiany stanu troficznego zbiorników retencyjnych. Ekonomia, Środowisko, 2(45).107-116.

54. Singleton V.L., Jacob B., Feeney M.T. Little J.C. 2013. Modeling a proposed quarry reservoir for raw water storage in Atlanta, Georgia. Journal of Environmental Engineering, 139(1), 70-78. DOI: 10.1061/(ASCE)EE.1943-7870.0000582.

55. Stottmeister U., Glässer W., Klapper H., Weißbrodt E., Eccarius B., Kennedy C., Schultze M., Wendt-Potthoff K., Frömmichen R., Schreck P., Strauch G. 1999. Strategies for Remediation of 
Former Opencast Mining Areas in Eastern Germany. In: Azcue J.M. (eds) Environmental Impacts of Mining Activities. Environmental Science. Springer, Berlin, Heidelberg, https://doi. org/10.1007/978-3-642-59891-3_16.

56. Tarjuelo J.M., De-Juan J.A., Moreno M.A., Ortega J.F. 2010. Review. Water resources deficit andwater engineering. Span J Agric Res, 8, 102-121.

57. Kaniszewski S., Treder W. 2018. Jakość wody do nawadniania, fertygacji, metody uzdatniania. [In] Walczak, J. (Ed.) Ograniczenie zanieczyszczenia azotem pochodzenia rolniczego metodą poprawy jakości wód. Fundacja na rzecz Rozwoju Polskiego Rolnictwa, Warszawa 2018.

58. Walczykiewicz T. 2014. Scenarios of water resources development in Poland up to 2030. Water Resources, 41(6), 763-773. DOI: 10.1134/ S0097807814060219.
59. Wiatkowski M., Rosik-Dulewska C., Kuczewski K., Kasperek R. 2013. Ocena jakości wody zbiornika Włodzienin w pierwszym roku funkcjonowania. Rocznik Ochrona Środowiska, 15, 2667-2682.

60. Wiejaczka Ł. 2011. Wpływ zbiornika Klimkówka na abiotyczne elementy środowiska przyrodniczego w wolnie Ropy. Prace geograficzne 229, IGiPZ PAN, Warszawa.

61. Wojtkowska M. 2014. Metale ciężkie w wodzie, osadach, roślinach Jeziora Zegrzyńskiego (Heavy metals in water, sediments and plants of the Zegrzyński Lake). Progress in Plant Protection, 54 (1), 5-101. DOI: http://dx.doi.org/10.14199/ppp-2014-017.

62. Tokarczyk-Dorociak K., Lorenc M.W., Jawecki B. Zych-Głuszyńska K. 2015. Post-industrial landscape transformationand its application for geotourism, education and recreation - an example of the Wide Mt. near Strzegom, Lower Silesia/ Poland. Z. Dt. Ges. Geowiss, 166 (2).195-203. 